\title{
PENERAPAN METODE FMEA DAN AHP DALAM PERUMUSAN STRATEGI PENGELOLAAN RESIKO PROSES PRODUKSI YOGHURT
}

\section{Application of FMEA and AHP to Formulating The Strategy of Yogurt Production Risk}

\author{
Muchlis Dwi Prasetiyo ${ }^{1}$, Imam Santoso ${ }^{2 *}$, Siti Asmaul Mustaniroh ${ }^{3}$, Purwadi $^{4}$ \\ 1, 2,3Jurusan Teknologi Industri Pertanian - Fakultas Teknologi Pertanian - Universitas Brawijaya \\ Jl. Veteran, Malang 65145 \\ ${ }^{4}$ Jurusan Teknologi Hasil Ternak - Fakultas Peternakan - Universitas Brawijaya \\ Jl. Veteran, Malang 65145 \\ *Penulis Korespondensi: email: imam.santoso.ub@gmail.com
}

\begin{abstract}
ABSTRAK
Analisa resiko produksi merupakan aspek penting dalam menjamin keberhasilan produksi dan bisnis. Riset ini bertujuan menganalisa resiko produksi yoghurt, mengidentifikasi faktorfaktor yang menyebabkan terjadinya resiko produksi yoghurt, dan strategi untuk meminimalkan resiko produksi yoghurt. Metode Failure Mode and Effect Analysis (FMEA) merupakan metode yang digunakan untuk mengidentifikasi resiko produksi yoghurt. Analitycal Hierarchy Process (AHP) digunakan untuk membantu penentuan alternatif strategi dalam meminimalkan resiko produksi yoghurt. Hasil penelitian menunjukkan resiko tertinggi dari masing-masing variabel. Resiko tersebut yaitu kualitas susu segar (susu mengandung bakteri patogen), proses produksi (kualitas bakteri starter menurun/mati), dan produk jadi (pesaing produk sejenis). Strategi untuk meminimasi resiko produksi yoghurt yaitu kualitas susu segar (pelatihan intensif bagi peternak), produk (kemitraan dengan pelaku bisnis lain), dan proses produksi (meningkatkan perawatan mesin dan peralatan)
\end{abstract}

Kata kunci : Analitycal Hierarchy Process, Failure Mode and Effect Analysis, Resiko Produksi, Yoghurt

\begin{abstract}
Production risk analysis is an important aspect for ensuring the success of the production and business. This research aimed to analyze the risks of yoghurt production, identify the factors that influence the risks of yoghurt production, and formulate the strategies to minimize the risks of yoghurt production. FMEA method was used to identify risk production and AHP was used to determine alternative strategies for minimizing the risk of yoghurt production. The results showed there are some the highest risks of each variable namely: milk contains bacterial pathogens, quality starter bacteria decreased/dead, and competitors that produce similar products. Strategies to manage the risk of the production of yoghurt, namely intensive training for the breeders to ensure the quality of fresh milk, partnership with other business person, and improving performance machinery and equipment
\end{abstract}

Keywords: Analitycal Hierarchy Process, Failure Mode and Effect Analysis, Production Risk, Yoghurt

\section{PENDAHULUAN}

Pertumbuhan produksi industri manufaktur besar dan sedang pada triwulan II tahun 2015, naik sebesar $2.34 \%$ dibandingkan triwulan I tahun 2015. Jenis industri yang mengalami kenaikan terbesar adalah industri makanan dan minuman, naik 9.84\% (BPS, 2015).
Data tersebut menunjukkan terjadi peningkatan permintaan akan produk. Meningkatnya permintaan tersebut menimbulkan persaingan yang ketat antar industri untuk memenuhi kebutuhan konsumen.

Koperasi XYZ merupakan salah satu industri minuman dengan produk yang dihasilkan berupa yoghurt. Proses produksi 
yoghurt sendiri meliputi pasteurisasi susu, pendinginan, penambahan bibit kefir, inkubasi, penyaringan, dan produk akhir yoghurt. Yoghurt hasil produksi Koperasi XYZ memiki 6 varian rasa yaitu leci, sirsak, melon, stroberi, anggur, dan jeruk. Kapasitas produksi yoghurt Koperasi XYZ saat ini sebesar 500 liter dengan wilayah distribusi meliputi Jawa Timur (Malang, Pasuruan, dan Sidoarjo) serta Bali. Pada aktivitas produksinya, resiko kegagalan merupakan faktor yang mempengaruhi kualitas produk yoghurt.

Resiko adalah potensi kejadian yang dapat merugikan yang disebabkan karena adanya ketidakpastian atas terjadinya suatu peristiwa (Yasa et al., 2013). Resiko dalam produksi tidak dapat dihilangkan, akan tetapi dapat diminimalkan dengan melakukan identifikasi resiko. Identifikasi resiko merupakan proses analisa untuk menemukan secara sistematis dan secara berkesinambungan resiko kerugian potensial yang menantang perusahaan (Barton dan Bobst, 1988; Tchankova, 2002; Darmawi, 2006; Hsu et al., 2015).

Permasalahan yang dihadapi Koperasi XYZ yaitu resiko kegagalan produksi yoghurt yang berdampak negatif bagi perusahaan. Kegagalan produksi tersebut berupa produk yang tidak sesuai dengan spesifikasi yang telah ditetapkan. Produk yang tidak sesuai dengan harapan tersebut dapat dipengaruhi oleh kualitas bahan baku ataupun pada proses produksinya. Dampak yang ditimbulkan produk cacat/rusak ini yaitu menurunnya daya saing produk ditengah persaingan yang semakin ketat. Jumlah kerusakan produk yoghurt pada Koperasi XYZ saat ini mencapai $10 \%$ dari total produksi.

Berdasarkan permasalahan diatas, maka perlu dilakukan penelitian analisa resiko produksi yoghurt di Koperasi XYZ untuk meminimalkan resiko. Metode yang digunakan yaitu Failure Mode and Effects Analysis (FMEA). FMEA merupakan teknik analisa yang mengkombinasikan teknologi dan pengalaman dalam mengidentifikasi kegagalan proses produksi dan merencanakan untuk mencegahnya terulang (Teng dan Ho, 1996; Santoso, 2007; Ahsen, 2008). Keunggulan FMEA yaitu memastikan produk akhir sesuai dengan spesifikasi, membantu desainer untuk mengidentifikasikan dan mengeliminasi atau mengendalikan cara kegagalan yang berbahaya, meningkatkan realibilitas dari produk (Teng dan Ho, 1996). Selanjutnya, dilakukan pembobotan tiap-tiap perspektif dengan menggunakan metode Analytical Hierarchy Process (AHP) untuk menentukan pilihan terbaik dari beberapa alternatif yang akan diambil. Keunggulan AHP yaitu mampu menjelaskan proses pengambilan keputusan, karena dapat digambarkan secara grafis, sehingga mudah dipahami semua pihak yang terlibat dalam pengambilan keputusan (Partovi et al., 1990; Marimin, 2004). Berdasarkan analisa di atas, maka tujuan penelitian ini adalah menganalisa resiko produksi yoghurt, mengidentifikasi faktorfaktor yang menyebabkan terjadinya resiko produksi yoghurt, dan strategi untuk meminimalkan resiko produksi yoghurt.

\section{BAHAN DAN METODE}

\begin{abstract}
Metode
Prosedur Penelitian

Prosedur penelitian merupakan tahap-tahap yang harus ditetapkan terlebih dahulu secara sistemastis dengan tujuan agar penelitian dapat dilakukan dengan terarah dan mempermudah dalam analisa permasalahan yang ada. Prosedur penelitian terdiri dari survei pendahuluan, identifikasi masalah, studi literatur, penentuan metode pengumpulan data, identifikasi variabel, penentuan pakar, penyusunan kuesioner, pengumpulan data, pengolahan dan analisa data, penarikan kesimpulan dan saran.
\end{abstract}

\section{Identifikasi Variabel}

Terdapat dua faktor yang diukur yaitu faktor resiko dan indikator resiko. Pengkajian pengukuran resiko-resiko yang dihadapi dapat dilihat pada Tabel 1.

\section{Pengolahan Data dengan Metode FMEA}

Metode FMEA mengidentifikasi resiko dengan menggunakan pertimbangan kriteria Severity (S), Occurrence $(\mathrm{O})$, dan Detection (D). Nilai $\mathrm{S}$ merupakan sebuah penilaian pada tingkat keseriusan suatu efek atau akibat dari potensi kegagalan pada proses yang dianalisa. Nilai $\mathrm{O}$ pada analisa mencerminkan probabilitas atau peluang terjadinya kegagalan yang terjadi, sedangkan nilai $\mathrm{D}$ adalah peluang terjadinya kegagalan yang dapat terdeteksi. 
Pengolahan Data dengan Metode AHP

Metode AHP digunakan untuk membantu pemilihan keputusan dari beberapa strategi. Strategi tersebut kemudian dilakukan pembobotan menggunakan perbandingan berpasangan. Bobot dengan nilai tertinggi merupakan strategi terpilih untuk meminimalkan resiko produksi yoghurt. Pengolahan data dengan AHP menggunakan software Expert choice.

\section{HASIL DAN PEMBAHASAN}

\section{Analisis Resiko Produksi}

Penilaian resiko produksi pada Koperasi XYZ terdiri dari 3 variabel yaitu kualitas susu segar, proses produksi, dan produk. Variabel tersebut memiliki beberapa indikator resiko yang kemudian diberikan penilaian. Penilaian bertujuan untuk

Tabel 1. Kajian dan pengukuran resiko produksi yoghurt

\begin{tabular}{ll}
\hline Faktor Resiko & \multicolumn{1}{c}{ Indikator Resiko } \\
\hline \multirow{3}{*}{ Kualitas Susu } & 1. Susu mengandung bakteri patogen \\
& 2. Berat jenis susu tidak sesuai standar \\
& 3. Rasa, warna, dan aroma susu tidak normal \\
& 4. Susu menggumpal/pecah \\
\hline & 1. Proses pasteurisasi susu tidak maksimal \\
& 2. Kontaminasi susu dengan lingkungan \\
Proses Produksi & 3. Kualitas bakteri menurun/mati \\
& 4. Suhu dan waktu inkubasi kurang terkontrol \\
& 5. Mesin dan peralatan tidak bekerja maksimal \\
\hline & 1. Kerusakan atau kehilangan saat penyimpanan \\
2. Pesaing produk sejenis \\
3roduk Jadi & 4. Reterlambatan pengiriman produk yoghurt kepada pelanggan \\
&
\end{tabular}

Tabel 2. Hasil perhitungan RPN resiko produksi yoghurt

\begin{tabular}{clccccc}
\hline $\begin{array}{c}\text { Faktor } \\
\text { Resiko }\end{array}$ & \multicolumn{1}{c}{ Indikator Resiko } & S & O & D & RPN & Peringkat \\
\hline \multirow{3}{*}{$\begin{array}{c}\text { Kualitas } \\
\text { susu }\end{array}$} & Susu mengandung bakteri pathogen & 9 & 4 & 8 & 288 & 1 \\
& Susu segar pecah & 6 & 4 & 8 & 192 & 2 \\
& Berat jenis susu tidak sesuai standar & 5 & 4 & 8 & 160 & 3 \\
& Rasa, warna, dan aroma susu tidak normal & 7 & 2 & 9 & 126 & 4 \\
\hline \multirow{5}{*}{$\begin{array}{c}\text { Proses } \\
\text { Produksi }\end{array}$} & Kualitas bakteri starter menurun/mati & 9 & 3 & 9 & 163 & 1 \\
& Suhu dan waktu inkubasi kurang terkontrol & 9 & 2 & 9 & 162 & 2 \\
& Proses pasteurisasi susu tidak maksimal & 9 & 2 & 8 & 144 & 3 \\
& Mesin dan peralatan tidak bekerja maksimal & 9 & 2 & 6 & 108 & 4 \\
& Kontaminasi susu dengan lingkungan & 4 & 3 & 6 & 72 & 5 \\
\hline \multirow{5}{*}{ Produk } & Pesaing produk sejenis & 7 & 7 & 7 & 343 & 1 \\
& Retur yoghurt ke perusahaan & 6 & 6 & 6 & 216 & 2 \\
& Keterlambatan pengiriman produk yoghurt & 5 & 5 & 5 & 125 & 3 \\
& kepada pelanggan & & & & & \\
& Kerusakan/kehilangan saat Penyimpanan & 3 & 3 & 3 & 27 & 4
\end{tabular}


mengetahui nilai risk priority number (RPN) berdasarkan kriteria saverity, occurance, dan detection. Ranking tertinggi/satu akan dijadikan prioritas dalam penentuan starategi untuk meminimalkan resiko. Hasil perhitungan RPN dari masing-masing indikator resiko dapat dilihat pada Tabel 2.

\section{Variabel Kualitas Susu Segar}

\section{Susu Mengandung Bakteri Patogen}

Pada faktor resiko kualitas susu segar, resiko tertinggi terjadi pada indikator susu mengandung bakteri patogen dengan RPN sebesar 288. Kondisi kandang sapi pada peternak sangat sempit dan minim cahaya sehingga kandang menjadi lembab dan baunya menyengat. Penggunaan minyak sebgai pelumas dalam pemerahan jarang diganti oleh peternak. Hal tersebut menyebabkan berkembangnya bakteri patogen dan mengontaminasi susu yang keluardariputing.Faktorlainyangmenunjang pertumbuhan bakteri patogen yaitu milk can. Peternak tidak menempatkan milk can setelah pencucian dalam posisi tertelungkup, melainkan dalam posisi sebaliknya. Hal ini menjadikam air sisa pencucian menggenang dan mudah terkontaminasi dengan debu ataupun kotoran. Kontaminasi bakteri pada raw milk umumnya berasal dari tiga sumber, yakni dalam puting, di luar puting, dan dari permukaan peralatan penanganan dan penyimpanan susu (Budiyono, 2009; Hou et al., 2015; Moorby et al., 2016).

\section{Susu Segar Pecah/Menggumpal}

Resiko tertinggi kedua ditempati oleh indikator resiko susu menggumpal atau pecah yang erat kaitannya dengan bakteri pada susu. Keadaan tersebut terjadi akibat aktivitas enzim yang menimbulkan reaksi kimia lebih cepat, sehingga terbentuk gumpalan pada susu. Enzim tersebut berasal dari mikroba atau sudah ada dalam susu secara normal. Menurut Nababan et al. (2015), susu pecah menunjukkan bahwa telah terjadi kerusakan dari air susu adalah tinggi. Pecahnya susu disebabkan oleh berkembangbiaknya bakteri asam susu, dalam hal ini laktosa diubah menjadi asam laktat.

\section{Berat Jenis Susu}

Berat jenis susu yang dihasilkan peternak pada Koperasi XYZ dipengaruhi oleh genetika, pakan dan kesehatan sapi peternak. Peternak yang memberikan pakan konsentrat lebih pada sapinya, susu yang dihasilkan akan memiliki berat jenis yang lebih tinggi pula. Penilaian berat jenis susu pada Koperasi XYZ yaitu 1.024 pagi hari dan 1.023 pada sore hari. Adanya penetapan syarat nilai berat jenis yang diterima Koperasi XYZ, menyebabkan beberapa peternak berbuat curang dengan mencampurkan susu dengan bahan tambahan seperti tepung. Menurut Utami et al. (2014), berat jenis dipengaruhi oleh kandungan yang terlarut didalam susu dimana semakin banyak senyawa yang terdapat dalam susu maka berat jenis susu akan meningkat.

\section{Rasa, Warna, dan Aroma susu}

Kondisi lingkungan yang kotor dan penanganan yang tidak maksimal, menjadi penyebab berkembangnya bakteri secara cepat. Kerusakan pada susu ditandai dengan perubahan rasa, warna dan aroma yang tidak sesuai standar. Susu segar memiliki rasa khas sedikit manis, bau mudah hilang, dan memiliki warna kekuning-kuningan. Pada umumnya susu segar yang belum tercemar tidak mengandung asam laktat (Robinson, 1993; Aritonang, 2010; Milagres et al., 2012; de Almeida Júnior et al., 2015). Menurut Nababan et al. (2014), susu yang baik berwarna putih kekuningan dan tidak tembus cahaya. Kerusakan susu ditandai dengan perubahaan warna dari warna aslinya dan baunya pun tidak khas seperti susu segar.

\section{Variabel Resiko Proses Produksi}

\section{Kualitas Bakteri Starter Menurun/Mati}

Resiko tertinggi ditempati oleh kualitas bakteri starter menurun/mati dengan RPN sebesar 163. Menurunnya kualitas bakteri starter disebabkan suhu pada mesin fermentor tidak stabil yang berpengaruh pada pertumbuhan bakteri. Pengadukan susu yang terlalu kuat oleh agitator juga mengakibatkan bakteri mati. Pada jangka waktu tertentu selama pertumbuhan, mikroba dalam starter tetap aktif dan mempertahankan sifat-sifat khasnya (Santoso, 1994; Jackson, 2014). Aktivitas tersebut dapat menurun tergantung kecocokan spesies dan varietas mikroba terhadap kondisi tersebut, hal ini disebabkan oleh kondisi fisik.

\section{Suhu dan Waktu Inkubasi}

Kurang terkontrolnya suhu dan waktu 
Jurnal Teknologi Pertanian Vol. 18 No. 1 [April 2017] 1-10

Penerapan Metode FMEA dan AHP dalam Perumusan Strategi Pengelolaan Resiko [Prasetiyo dkk.]
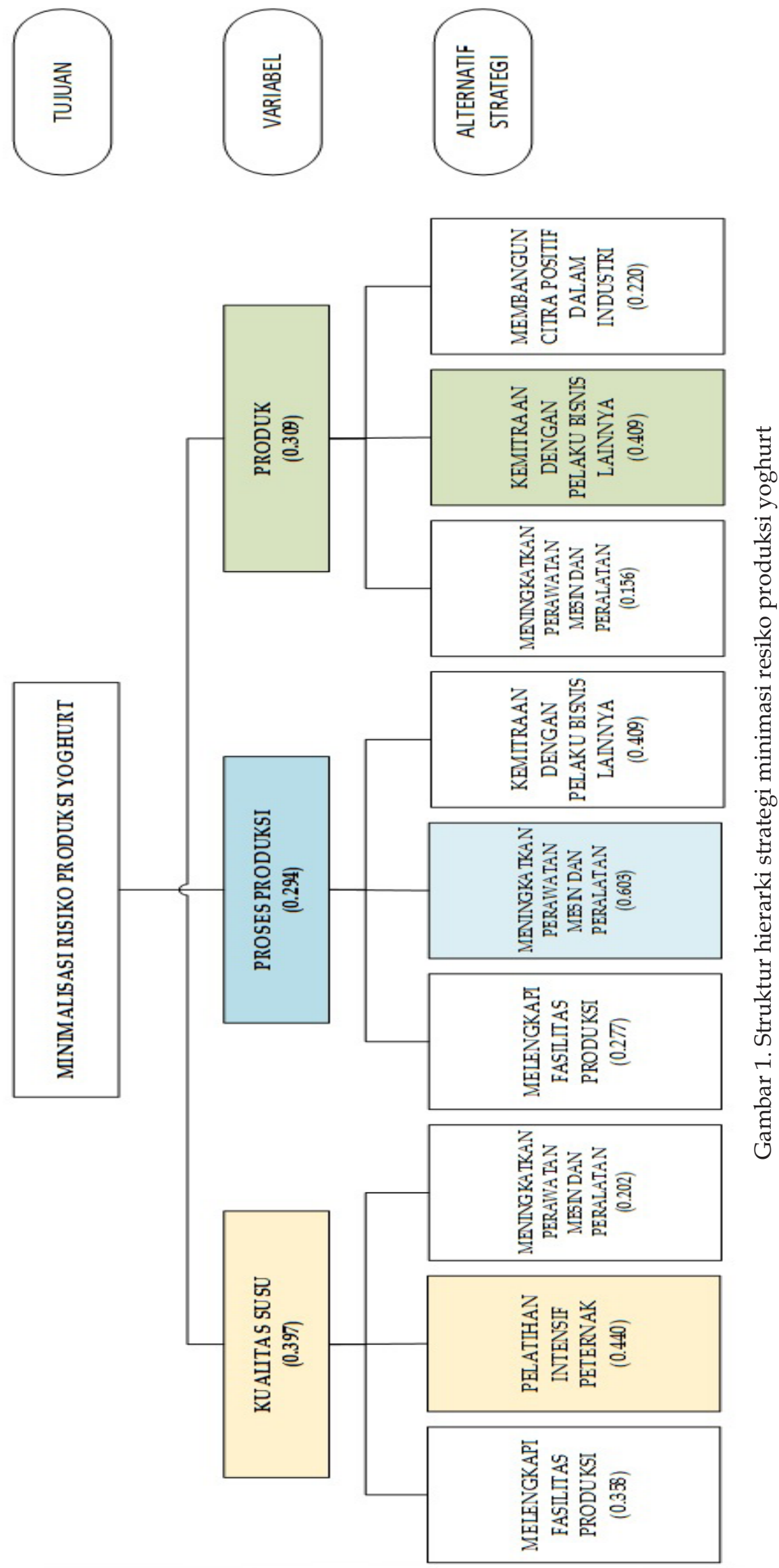
inkubasi susu di Koperasi XYZ disebabkan oleh faktor alat yang tidak bekerja maksimal. Alat tersebut tidak bekerja maksimal akibat arus listrik yang naik turun. Suhu dan waktu yang dibutuhkan untuk inkubasi susu yaitu $45{ }^{\circ} \mathrm{C}$ selama 5-6 jam. Karyawan terkadang lupa melakukan pengecekan suhu inkubator sehingga hasil inkubasi kurang maksimal. Bertambahnya waktu inkubasi, aktivitas mikroba semakin meningkat dan jumlah mikroba semakin banyak, sehingga mengakibatkan $\mathrm{pH}$ medium menjadi turun. Hal ini membuktikan terjadinya perubahan kimia pada komponen gula menjadi komponen asam (Muawanah, 2007; Medeiros et al., 2015).

\section{Pasteurisasi Susu}

Kurang maksimalnya proses pasteurisasi susu disebabkan oleh elemen panas pada mesin PHE tertutupi oleh kotoran. Hal tersebut diakibatkan proses Clean in Process (CIP) yang kurang sempurna, sehingga suhu pemanasan menjadi tidak stabil/menurun. Akibat yang ditimbulkan yaitu kualitas yoghurt menurun akibat mesin tidak bekerja optimal. Keandalan mesin dan fasilitas produksi merupakan salah satu aspek yang dapat mempengaruhi kelancaran proses produksi serta produk yang dihasilkan. Keandalan ini dapat membantu untuk memperkirakan peluang suatu komponen mesin untuk dapat bekerja sesuai dengan tujuan yang diinginkan dalam periode tertentu (Sayuti et al., 2013).

\section{Mesin dan Peralatan Produksi}

Mesin dan peralatan produksi memiliki peran penting dalam berlangsungnya proses produksi yoghurt. Kebutuhan listrik yang lebih tinggi dari kapasitas yang tersedia menyebabkan terhentinya mesin produksi. Beberapa mesin yang digerakkan menggunakan energi listrik yaitu blending, PHE, homogenizer, dan fermentor. Menurut Muhtadi (2009), kesiapan fasilitas dalam kegiatan operasional lebih baik, karena kerusakan yang terjadi pada peralatan bisa berkurang karena adanya sistem perawatan yang baik dan teratur. Pelayanan yang sederhana dan teratur dapat mengurangi kemacetan produksi, lebih cepat dan murah daripada memperbaiki kerusakan yang terjadi secara tiba-tiba.

\section{Kontaminasi dengan Lingkungan}

Kontaminasi dapat diakibatkan kondisi lingkungan produksi di Koperasi XYZ yang kotor, seperti terdapat sarang laba-laba pada sudut-sudut tembok dan jendela berdebu. Kondisi tersebut secara tidak langsung akan berpengaruh terhadap shelf life produk. Terdapat karyawan yang tidak mematuhi penggunaan alat pelindung diri seperti masker. Hygiene dan sanitasi merupakan hal yang penting dan saling berhubungan dalam proses pengolahan makanan. Apabila hygiene dan sanitasi dapat terpenuhi dengan baik, maka makanan yang disajikan oleh konsumen akan memenuhi kualitas yang baik pula, karena konsumen yang memesan makanan berharap makanan yang dipesannya dalam keadaan bersih, sehat, enak, menarik (Rakhmawati dan Wisnu, 2015).

\section{Variabel Resiko Produk}

\section{Pesaing Produk Sejenis}

Hasil perhitungan pada Tabel 2 menunjukkan resiko tertinggi ditempati oleh indikator resiko pesaing produk sejenis dengan nilai RPN 343. Konsumen cenderung lebih mempercayakan pilihannya terhadap produk yoghurt dari perusahaan ternama. Mereka yakin bahwa yoghurt dari perusahaan ternama memiliki kualitas yang jauh lebih baik. Tercapainya kepuasan pelanggan maka dapat membentuk penilaian positif, sehingga mendorong konsumen untuk tetap berkeinginan melakukan keputusan pembelian pada produk tersebut (Djatikusuma dan Getrycia, 2014; Agnihotri et al., 2016; Echchakoui, 2016; Murali et al., 2016).

\section{Pengembalian Produk ke Perusahaan}

Pengembalian produk yoghurt dikarenakan adanya kerusakan produk akibat masa kadaluarsa yang lebih cepat. Hal tersebut dikarenakan suhu penyimpanan yang kurang maksimal pada outlet penjualan. Retur produk ke perusahaan berdampak tingginya biaya kerusakan dan terjadinya limit stock. Retur barang dapat terjadi karena kesalahan produksi yang meliputi label rusak, botol cacat, isi botol tidak standar, karton rusak, tutup botol dol, terjadi fermentasi lanjutan, dan belum masa kadaluarsa (Flygansvaer et al., 2008; Royan, 2009; Li, 2011). 


\section{Keterlambatan Pengiriman Yoghurt}

Keterlambatan pengiriman di

Koperasi XYZ terjadi karena stok yang tidak selalu tersedia dan kondisi jalan macet saat pengiriman. Dampak yang ditimbulkan yaitu adanya keluhan pelanggan dan menurunkan daya saing produk. Mengatasi hal ini maka jumlah persediaan harus ditingkatkan sampai batas yang ekonomis.

\section{Kerusakan/Kehilangan SaatPenyimpanan}

Pada outlet penjualan, penerapan prosedur penyimpanan pada suhu $4{ }^{\circ} \mathrm{C}$ oleh karyawan terkadang tidak dijalankan dengan baik. Ketidaksesuaian suhu tersebut berdampak pada berkembangnya mikroba merugikan, yang menjadikan yoghurt lebih cepat rusak dan menurun kualitasnya. Berubahnya warna dan pemisahan antara kadar air dan whey merupakan bentuk penurunan kualitas produk. Suhu penyimpanan produk yoghurt yaitu 4-5 ${ }^{\circ} \mathrm{C}$ yang berfungsi untuk menghentikan proses fermentasi (Effendi et al., 2009). Masa simpan produk makanan pada umumnya dipengaruhi oleh beberapa faktor seperti misalnya paparan cahaya, panas, kelembaban, reaksi enzimatik dan kontaminasi mikroba dan tergantung pula dengan kualitas kemasannya (Mataragas et al., 2011; Surono, 2016).

\section{Perumusan Strategi dengan AHP}

Nilai bobot dari masing-masing variabel dan strategi dapat dilihat pada Gambar 1.

\section{Strategi Minimasi Resiko Kualitas Susu Segar}

Strategi pelatihan intensif peternak menempati peringkat 1 dengan nilai bobot 0.440. Hasil perhitungan AHP menunjukkan strategi yang tepat untuk meminimasi resiko pada kualitas susu segar yaitu pelatihan intensif peternak. Pelatihan tersebut dilakukan dengan pemberian pengetahuan mengenai good farming practices pada peternak secara intensif. Good dairy farming practices (GDFP) adalah suatu standarisasi usaha peternakan sapi perah. Aspek utama dalam GDFP yaitu reproduksi ternak, kesehatan ternak, hygiene pemerahan, nutrisi (pakan dan air), kesejahteraan ternak, lingkungan, dan manajemen sosial ekonomi (Tauer, 2002; Lestari et al., 2015; Weeks et al., 2015). Pelatihan tersebut kemudian dilakukan pengontrolan secara rutin pada peternak. Pengontrolan bertujuan mengetahui bahwa peternak benar-benar menerapkan prosedur pemerahan dengan baik dari hasil pelatihan. Peningkatan keahlian karyawan dapat memberikan kontribusi yang baik bagi perusahaan dan dapat memberikan tingkat efisiensi dalam melakukan suatu pekerjaan (Markos dan Sridevi, 2010; Sembiring, 2010).

\section{Strategi Minimasi Resiko Produk}

Strategi kemitraan dengan pelaku bisnis lain diketahui memiliki bobot tertinggi yaitu 0.409. Kemitraan adalah bentuk kerjasama usaha antara dua pihak dengan saling menguntungkan dan meningkatkan pendapatan sehingga tercapai tujuan usaha. Kerjasama pemasaran sebagai strategi dalam memasarkan yoghurt mampu memberikan keunggulan bersaing terhadap produk sejenis. Adanya kerjasama dengan distributor, agen, retailer, dan sales, akan meningkatkan kualitas pelayanan dan produk kepada pelanggan. Konsumen akan dengan mudah memperoleh produk yoghurt. Selain itu, penjualan yoghurt akan meningkat karena pemasaran produk yang semakin luas dan dikenal konsumen. Supaya tetap dapat survive di pasar global perlu adanya organization network, tidak dalam pengertian bersama-sama dengan perusahaan satu grup dalam satu hubungan keluarga (induk dan anak perusahaan), namun dengan jalan menjalin kemitraan usaha dengan perusahaan lain melalui partner relationship dengan pemasok (vertikal) dan melalui strategic alliance dengan mitra bisnis terkait (horizontal) (Mulyadi, 2007; Kusumasari, 2012; Ihm, 2015).

\section{Strategi Minimasi Resiko Proses}

Strategi meningkatkan perawatan mesin dan peralatan menempati peringkat pertama dengan bobot 0.603 . Menurunnya kualitas/kerusakan pada starter dikarenakan kondisi fisik yang tidak sesuai. Starter akan berkembang dengan baik apabila suhu dan waktu inkubasi yang tepat. Menurut Santoso (1994), inkubasi dilakukan pada suhu 45 ${ }^{\circ} \mathrm{C}$ selama 5 jam, atau $32{ }^{\circ} \mathrm{C}$ selama 11 jam. Apabila inkubasi dilakukan pada suhu ruang (sekitar $29^{\circ} \mathrm{C}$ ), memerlukan 14-16 jam. Pada proses produksi tersebut, digunakan mesin fermentor untuk menginkubasi susu. Suhu pada mesin fermentor mengalami perubahan akibat performa mesin yang tidak 
maksimal. Perawatan secara berkala akan menunjang kelancaran aktivitas produksi, menjaga performa mesin dan menghasilkan produk sesuai yang diharapkan. Menurut Muhtadi (2009), pelaksanaan manajemen pemeliharaan terhadap mesin-mesin agar dapat terjaga sebuah kondisi atau standar yang dapat diterima atau dibutuhkan agar semua fasilitas dalam kondisi siap pakai, sehingga mampu menciptakan kegiatan yang terencana untuk mendapatkan optimalisasi laba.

\section{SIMPULAN}

Pada variabel kualitas susu segar terdapat empat resiko yaitu susu mengandung bakteri patogen, susu segar pecah, berat jenis tidak sesuai standar, dan rasa, aroma, warna tidak normal. Pada variabel proses produksi terdiri dari lima resiko yaitu kualitas bakteri starter menurun/mati, suhu dan waktu inkubasi kurang terkontrol, proses pasteurisasi susu kurang terkontrol, mesin dan peralatan tidak bekerja maksimal, dan kontaminasi susu dengan lingkungan. Pada variabel produk terdapat resiko pesaing produk sejenis, retur yoghurt ke perusahaan, keterlambatan pengiriman produk yoghurt kepada pelanggan, dan kerusakan/kehilangan saat penyimpanan. Hasil penilaian resiko produksi yoghurt dengan metode FMEA, didapatkan resiko tertinggi dari masing-masing variabel. Resiko tersebut yaitu kualitas susu segar (susu mengandung bakteri patogen), proses produksi (kualitas bakteri starter menurun/ mati) dan produk (pesaing produk sejenis). Berdasarkan perhitungan AHP diperoleh tiga alternatif strategi untuk meminimasi resiko dari masing-masing variabel. Alternatif strategi tersebut yaitu kualitas susu segar (pelatihan intensif bagi peternak), produk (kemitraan dengan pelaku bisnis lain), dan proses produksi (meningkatkan perawatan mesin dan peralatan).

\section{DAFTAR PUSTAKA}

Agnihotri, R, Dingus, R, Hu, M, Y, Krush, M, T. 2016. Social media: Influencing customer satisfaction in B2B sales. Industrial Marketing Management. 53:172-180
Ahsen, A, V. 2008. Cost-oriented failure mode and effects analysis. International Journal of Quality \& Reliability Management. 25(5):466-476

Aritonang, SN. 2010. Susu dan Teknologi. Swagati Press, Cirebon

Barton, R, Bobst, R. 1988. How to manage the risks of technology. Journal of Business Strategy. 9(6):4-7

BPS. 2015. Pertumbuhan produksi IBS naik sebesar 5.44\% dan IMK naik 4.57\% pada QII-2015 dari QII-2014. Dilihat 9 Juni 2016. <https://www.bps.go.id/ $\mathrm{Brs} / \mathrm{view} / \mathrm{id} / 1166>$

Budiyono, H. 2009. Analisis daya simpan produk susu pasteurisasi berdasarkan kualitas bahan baku mutu susu. Jurnal Paradigma. 10(2): 198-211

Darmawi, H. 2006. Manajemen Resiko. Bumi Aksara, Jakarta

de Almeida Júnior, W, L, G, Ferrari, I, S, de Souza, J, V, da Silva, C, D, A, da Costa, M, M, Dias, F, S. 2015. Characterization and evaluation of lactic acid bacteria isolated from goat milk. Food Control. 53:96-103

Djatikusuma, E, S, Getrycia, W. 2014. Analisis faktor-faktor yang mempengaruhi keputusan pembelian konsumen pada produk minuman berisotonik pocari sweat. Dilihat 9 Juni 2016. <http:// eprints.mdp.ac.id/747/1/jurnal $\% 20$ 2009200041\%20wanda\%20getrycia.pdf>

Echchakoui, S. 2016. Relationship between sales force reputation and customer behavior: Role of experiential value added by sales force. Journal of Retailing and Consumer Services. 28:54-66

Effendi, M, H, Sorini, H, Lusiastuti, A, M. 2009. Peningkatan kualitas yoghurt dari susu kambing dengan penambahan bubuk susu skim dan pengaturan suhu pemeraman. J. Penelit. Med. Eksakta. 8(3):185-192

Flygansvaer, B, M, Gadde, L, E, Haugland, S, A. 2008. Coordinated action in reverse distribution systems. International Journal of Physical Distribution \& Logistics Management. 38(1):5-20

Hou, Q, Xu, H, Zheng, Y, Xi, X, Kwok, L, Y, Sun, Z, Zhang H, Zhang, W. 2015. Evaluation of bacterial contamination in raw milk, ultra-high temperature milk and infant formula using single molecule, real-time sequencing technology. Journal of Dairy Science. 98(12):8464-8472 
Hsu, P, H, Lee, H, H, Liu, A, Z, Zhang, Z. 2015. Corporate innovation, default risk, and bond pricing. Journal of Corporate Finance. 35:329-344

Ihm, J. 2015. Network measures to evaluate stakeholder engagement with nonprofit organizations on social networking sites. Public Relations Review. 41(4):501-503

Jackson, RS. 2014. 'Fermentation'. Dalam Jackson, RS. Wine Science. Academic Press, Tokyo

Kusumasari, B. 2012. Network organisation in supporting post-disaster management in Indonesia. International Journal of Emergency Services. 1(1):71-85

Lestari, N, F, Makin, M, Firman, A. 2015. Hubungan antara penerapan good dairy farming practice dengan tingkat pendapatan peternak pada peternakan sapi perah rakyat (suatu kasus di wilayah kerja KPBS pangalengan kabupaten bandung). Student e-journals. 4(3):1-16

Li, Y. 2011. Study on operating performance of listed companies in electronic information industry. Procedia Environmental Sciences. 10:344-349

Marimin. 2004. Teknik dan Aplikasi Pengambil Keputusan Kriteria Majemuk. Gramedia Widiasarana Indonesia, Jakarta

Markos, S, Sridevi, M, S. 2010. Employee engagement: the key to improving performance. IJBM. 5(12):89-96

Mataragas, M, Dimitriou, V, Skandamis, P, N, Drosinos, E, H. 2011. Quantifying the spoilage and shelf-life of yoghurt with fruits. Food Microbiology. 28(3):611-616

Medeiros, A, C, Souza, D, F, Correia, R, T, P. 2015. Effect of incubation temperature, heat treatment and milk source on the yoghurt kinetic acidification. IFRJ. 22(3):1030-1036

Milagres, M, P, Brandão, S, C, C, Magalhães, M, A, Minim, V, P, R, Minim, L, A. 2012. Development and validation of the high performance liquid chromatography-ion exclusion method for detection of lactic acid in milk. Food Chemistry. 135(3):1078-1082

Moorby, J, M, Ellis, N, M, Davies, D, R. 2016. Assessment of dietary ratios of red clover and corn silages on milk production and milk quality in dairy cows. Journal of Dairy Science. 99(10):79827992
Muawanah, A. 2007. Pengaruh lama inkubasi dan variasi jenis starter terhadap kadar gula, asam laktat, total asam dan $\mathrm{pH}$ yoghurt susu kedelai. Jurnal Kimia Valensi. 1(1):1-6

Muhtadi, M, Z, Z. 2009. Manajemen pemeliharaan untuk optimalisasi laba perusahaan. Jurnal Pendidikan Akuntansi Indonesia. 8(1): 35-43

Mulyadi. 2007. Sistem Perencanaan dan Pengendalian Manajemen. Salemba Empat, Jakarta

Murali, S, Pugazhendhi, S, Muralidharan, C. 2016. Modelling and Investigating the relationship of after sales service quality with customer satisfaction, retention and loyalty - a case study of home appliances business. Journal of Retailing and Consumer Services. 30:67-83

Nababan, L, A, Suada, I, K, Swacita, I, B, N. 2014. Ketahanan susu segar pada penyimpanan suhu ruang ditinjau dari uji tingkat keasaman, didih, dan waktu reduktase. Indonesia Medicus Veterinus. 3(4):274-282

Nababan, L, A, Suada, I, K, Swacita, I, B, N. 2015. Kualitas susu segar pada penyimpanan suhu ruang ditinjau dari uji alkohol, derajat keasaman dan angka katalase. Indonesia Medicus Veterinus,. 4(4): 374-382

Partovi, F, Y, Burton, J, Banerjee, A. 1990. application of analytical hierarchy process in operations management. International Journal of Operations $\mathcal{E}$ Production Management. 10(3):5-19

Rakhmawati, N, Hadi, W. 2015. Peranan higiene dan sanitasi dalam proses pengolahan makanan di hotel brongto yogyakarta. Jurnal Khasanah Ilmu. 6(1):79-87

Robinson, R, K. 1993. Lactic acid bacteria. British Food Journal. 95(4):29-30

Royan, FM. 2009. Distributorship Management. Gramedia Pustaka Utama, Jakarta

Santoso, H, B. 1994. Teknologi Tepat Guna Susu dan Yoghurt Kedelai. Kanisius, Indonesia

Santoso, S. 2007. Seri Solusi Bisnis TI: Total Quality Management (TQM) dan Six Sigma. Elex Media Komputindo, Jakarta

Sayuti, M, Muhammad, Rifa'i, M, S. 2013. Evaluasi manajemen perawatan mesin dengan menggunakan metode reliability centered maintenance pada pt z. MIEJ Journal. 2(1): 9-13 
Jurnal Teknologi Pertanian Vol. 18 No. 1 [April 2017] 1-10

Penerapan Metode FMEA dan AHP dalam Perumusan Strategi Pengelolaan Resiko [Prasetiyo dkk.]

Sembiring, J J. 2010. Smart HRD: Perusahaan Tenang, Karyawan Tenang. Visimedia, Jakarta

Surono, IS, Sudibyo, A, Waspodo, P. 2016. Pengantar Keamanan Pangan Untuk Industri. Deepublish, Yogyakarta

Tauer, L, W. 2002. Estimating risk-adjusted interest rates for dairy farms. Agricultural Finance Review. 62(1):59-68

Teng, S, H, Ho, S, Y. 1996. Failure mode and effects analysis: An integrated approach for product design and process control. International Journal of Quality E Reliability Management. 13(5):8-26

Tchankova, L. 2002. Risk identification-basic stage in risk management. Environmental Management and Health. 13(3):290297
Utami, K, B, Radiati, L, E, Surjowardojo, P. 2014. Kajian kualitas susu sapi perah PFH (studi kasus pada anggota koperasi agro niaga di kecamatan jabung kabupaten malang). Jurnal Ilmu-Ilmu Peternakan. 24(2):58-66

Weeks, H, L, Frederick, T, W, Hagan, L, M, Heyler, K, Hristov PAS, A, N. 2015. Case study: Farm-level evaluation of implementing nitrogen and phosphorus feeding best management practices on Pennsylvania dairy farms. The Professional Animal Scientist. 31(5):573-483

Yasa, I, W, W, Sila Dharma, I, G, B, Ketut Sudipta, I, G. 2013. Manajemen resiko operasional dan pemeliharaan tempat pembuangan akhir (TPA) regional bangli di kabupaten bangli. Jurnal Spektran. 1(2): 30-38 